\title{
DESAKRALISASI TRADISI KEAGAMAAN: STUDI TENTANG PERUBAHAN MAKNA SIMBOLIK ISTIGHOSAH DI JAWA TIMUR
}

\author{
Oleh: Rubaidi*
}

\section{Abstract}

As a symbol system, istighosah ritual can be categorized as a part of slametan ritual. However, substantively, it is viewed from its motif and target and also its forms of execution; there is a difference between istighosah and slametan. Slametan ritual is understood as form of syncretism of Java Islam. But, istighosah ritual is assumed as more "genuine", as a part of traditional santri community tradition rooted from a big tradition of Islam (bigh Islam) in Middle East. But it is too bad that istighosah ritual has not been studied by observer elaborating study of local tradition and Islam in Indonesia. Finding of this study seems to have a shifting of orientation and also other deep meaning change which can be expressed. At the genuine concept of Istighosah, it emphasizes on two elementary aspect; (1) Target motif and (2) Form of application. Its field study shows the gradual change of "contemporary" istighosah execution starting to exit from this "track". There is a cultural system change at the group of traditional Muslim entity. To analyze it, this research use the perspective of Geertz's symbolic-interpretative as a theoretical framework.

كنظام رموز دلالي، يعتبر طقس الاستغاثة شكلأ من أشكال لقاءات الدعاء طلبأ للسلامة أو ما يسمى في إندونيسيا بــ "سلاماتان". غير أن النظر في محتوى وهدف وشكل تنفيذ لقاء الاستغائة، يظهر وجود فروقات بينه وبين سلاماتان. تحاول الدراسة الحالية التعرف على تلك الفروقات من خحلال استخدام إطار

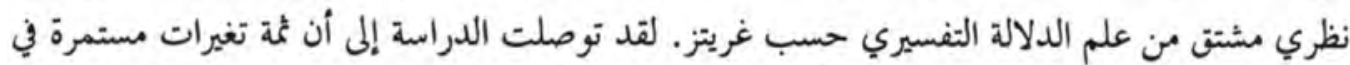
هدف وشكل تنفيذ طقس الاستغائة، وأن هذه التغيرات تعكس التغيرات الحادئة في الثقافة المحلية نحو التهر التحديث بشكل عام.

Keywords: Istighosah, Estetisasi Agama, dan Kyai-santri 


\section{A. Pendahuluan}

Istighosah dalam bahasa Arab dapat diartikan sebagai "meminta pertolongan". Istilah ini diambil dari lafal doa "Yâ Hayyu yâ Qoyyûm birohmatika astaghits!" (Wahai Dzat Yang Mahab Hidup dan yang tidak butuh pertolongan, berilah pertolongan kepadaku!). ${ }^{1}$ Praktik ritual ini sebenarnya telah lama menjadi bagian dari tradisi keagamaan warga NU, khususnya mereka yang tergabung dalam kelompok tarekat. Namun, sayangnya ritual ini tidak banyak dikaji oleh para pemerhati yang mengkaji tentang NU atau Islam tradisional pada umumnya. Simbol yang selalu saja digunakan untuk melihat dan mengkaji Islam tradisional mengacu pada ritual slametan.

Hal ini nampak sekali pada kajian Geertz, Beatty, Hefner, Mulder, Woodward, dan masih banyak lagi. Karena itu, dapat dipastikan, ritual istighosah memiliki akar dan benang merah langsung dengan tradisi besar Islam (bigh Islam) dari Timur Tengah, Arab. Ritual istighosah bukan meniru atau berbau sinkretisme tradisi Hindu (slametan). Hal ini karena, di negara-negara Arab kata istighotsah dipakai sebagai satu peristilahan yang berarti doa khusus saja yang ucapkan oleh seorang tokoh. Hal ini sama dengan makna genuine ritual istighosah bagi kalangan tarekat di Indonesia.

Ritual istighosah secara umum dapat dikatagorikan sebagai slametan. Jika tradisi slametan ditengarahi ada pengaruh tradisi ritual hindu, sementara ritual istghosah diambil dari tradisi jama'ah tarekat. Pada awalnya, ritual istighosah di kalangan tarekat dilaksanakan dengan prinsip tadarruan wa hufyah (ratapan dan ketakutan), di ruang tertutup dengan bimbingan seorang mursyid (guru Tarekat). ${ }^{2}$ Bacaan antara slametan dan istighosah juga berbeda. Ritual istighosah dalam tradisi muslim tradisional sebenarnya telah ada dan berjalan lama. Namun, ritual ini populer memasuki akhir tahun 1990-an, saat para kiai Nahdlatul Ulama berinisiatif mengajak umat Islam dan bangsa Indonesia untuk berdoa, meminta pertolongan kepada Allah, secara bersama-sama di tempat yang tidak lagi tertutup, tetapi terbuka.

Menilik dari sistem istighosah sebagaimana konsepsi sesungguhnya, ia sebenarnya lebih kompleks dari pada sistem yang ada dalam upacaya slametan. Hanya saja istilah slametan rupanya telah lama populer dan telah menjadi sistem simbol yang dikembangkan oleh para peneliti (barat) untuk menjelaskan makna dibalik yang tersurat itu. Kiranya tidak masalah jika sistem simbol pada ritual istighosah dapat dipahami sebagai bagian dari ritual slametan itu sendiri. Jika upacaya

1 NU Online, Mengawali Istighosah, 19 Januari 2007.

2 NU Online, Mengawali Istighosah, ..., Ibid. 
slametan memiliki fungsi sendiri, begitu juga dengan istighosah.

Perspektif simbolik-interpretatif dalam kajian Islam, khususnya untuk konteks tradisi lokal yang menjadikan slametan sebagai sistem simbol, digunakan untuk memahami sistem nilai dan sistem kognitif dari suatu kebudayaan masyarakat Islam lokal. Para ahli barat telah banyak menggunakan pendekatan ini. Meskipun mendasarkan atas pemahaman terhadap sistem simbol yang sama, tetapi hasil kesimpulan tidak selalu sama, alias berbeda. Hal ini dapat ditunjukkan pada beberapa kajian terdahulu tentang ritual slametan pada tradisi muslim Jawa.

Hasil pengamatan para ahli tentang Islam Jawa menghasilkan dua kesimpulan berbeda; (1) Pendapat yang mengatakan Islam Jawa bersifat "sinkretis" dan (2) Islam Jawa lebih berwatak "akulturatf”. Kelompok pertama diwakili oleh Geertz dalam karya monumentalnya, "Abangan, Santri, Priyayi dalam masyarakat Jawa". Kesimpulan Geertz berangkat dari pemaknaan terhadap simbol-simbol dalam slametan, dengan konklusi, bahwa Islam Jawa adalah Islam sinkretik. ${ }^{3}$ Senada dengan Geertz yang menempatkan sinkretisme Islam Jawa melalui simbol slametan adalah temuan Andrew Beatty, ${ }^{4}$ dan Niels Mulder. ${ }^{5}$ Sebaliknya, beberapa hasil studi serupa yang menghasilkan kesimpulan bertolak belakang (Islam akulturatif) di antaranya dilakukan oleh Hefner, ${ }^{6}$ dan Woodward. ${ }^{7}$

Perkembangan ritual slametan dari hari ke hari tidak mengalami perubahan.

3 Bagi Geertz, slametan dianggap sebagai media ritual tempat bertemunya antara golongan abangan dan sebagian santri (muslim tradisional). Karena, keduanya menggunakan media slametan sebagai saranya untuk beribadah (berdoa). Lihat, Harsja W. Bachtiar, dalam Clifford Geertz, Abangan, Santri, Priyayi dalam Masyarakat Jawa, (Jakarta: Pustaka Jaya, 1983), hal. 536.

4 Dalam penelitiannya di Banyuwangi, Beatty juga bersimpulan, bahwa slametan sebagai sistem simbol juga penuh dengan tradisi anismistik dan hindu yang diintrodusir ke dalam praktek Islam. Lihat Andrew Beatty, Variasi Agama di Jawa: Suatu Pendekatan Antropologi, Jakarta: PT. Rajagrafindo Persada, 2001), hal. 39-40.

5 Istilah yang dipakai oleh Mulder untuk menggambarkan tentang sinkretisme adalah "lokalisasi". Konsep ini artinya sama dengan sinkretisme. Lihat Niels Mulder, Agama, Hidup seharihari dan Perubahan Budaya, (Jakarta: Gramedia Pustaka Utama, 1999), hal. 3-19. Baca juga Niels Mulder, Mistisisme Jawa: Ideologi di Indonesia, (Yogyakarta, LkiS, 2007), hal. 243-248.

${ }_{6}$ Dalam temuan penelitiannya di Tengger-Bromo, ia menyimpulkan, bahwa dalam elemenelemen masyarakat Hindu Tengger banyak dijumpai adanya elemen Islam. Lihat Robert W. Hefner, Hindu Javanes: Tengger Tradition and Islam, (Princeton: Princeton University Press, 1985).

Berbeda dengan Geertz atau yang lainnya, Woodward yang meneliti tentang tradisi yang sama di pusat budaya Jawa, yakni Jogyakarta tiba pada kesimpulan, bahwa Islam Jawa walaupun banyak mengadopsi unsur lokal, tetapi keberadaannya tetaplah genuine dan memiliki tradisi langsung dengan Islam di Timur Tengah. Lihat Mark Woodward, Islam Jawa: Kesalehan Normatif Versus Kebatinan, (Yogyakarta: LKiS, 2006). 
Tetapi, ritual yang sama dengan slametan, yakni istighosah menunjukkan dinamika makna berbeda. Pengamatan mendalam terhadap ritual yang satu ini menampakkan ada dinamika perubahan makna. Temuan di lapangan mengindikasikan adanya narasi besar perubahan sistem kebudayaan pada kelompok muslim tradisional. Indikasinya nampak dari penyelenggaraan ritual istighosab satu ke yang lainnya telah ditemukan adanya perubahan, baik pada tataran konsep tujuan maupun dari bentuk (packing) kemasan. Jika merujuk pada tatacara maupun motif pelaksanaan istighosah, konsep genuine (asli) dari ritual istighosah sebenarnya paling tidak ada 2 (dua) hal penting:

Pertama, tujuan istighosah untuk memohonan pertolongan Tuhan dalam kondisikondisi yang benar-benar terdesak, rasio manusia tidak lagi memahami sepenuhnya terhadap masalah yang terjadi, dan kekuatan fisik manusia juga dirasa tidak akan mampu menyelesaikan permasalahan yang ada. Kedua, bentuk (packing) pelaksanaannya juga ditempat yang hening, sepi, jauh dari keramaian, apalagi di tempat terbuka atau lapang. Dua aspek penting ini, kiranya lambat laun ditinggalkan, kalau tidak menyebut diabaikan. Sebab, dalam kenyataan sekarang, istighosah justru digelar dengan motif

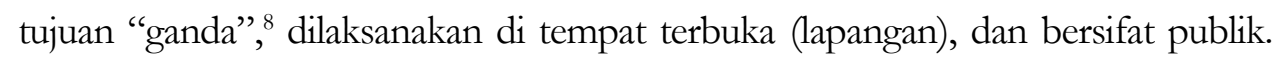

Sebagai bagian dari sistem kebudayaan, fenomena ritual istighosah rupanya menarik untuk diteliti. Bukan hanya karena upacara istighosah masih dapat digolongkan dari "varian" ritual slametan di kalangan Islam tradisional (NU). Lebih dari itu, istighosah nampaknya dalam banyak hal -nantinya-dianggap paling dinamis karena mengalami perubahan dibanding ritual slametan itu sendiri. Terhadap kasus dan obyek penelitian yang sama, penelitian ini tidak hendak ingin membenarkan atau menyalahkan hasil temuan para ahli di atas. Tulisan ini juga tidak berkehendak untuk menguji salah satu teori atau kedua-duanya. Sebaliknya, positioning tulisan ini hendak menjawab beberapa pertanyaan; (1) Apa dan bagaimana (hakekat) sesungguhnya ritual istighosah itu? (2) Nilai-nilai perubahan apa yang terjadi dalam ritual istighosah melalui sistem simbol yang hadir dan mengitari di beberapa proses penyelenggaraan ritual tersebut? Namun, sebelum menyajikan analisis kajian, ada lebih baiknya digambarkan setting penelitian guna menyakinkan hasil temuan penelitian ini nantinya.

8 Motif tujuan penyelenggaran istighosah selalu saja dikatakan, bahwa kondisi bangsa, masyarakat dan tataan sosial-politik bangsa ini dalam keadaan darurat. Namun, indikator-indikatornya selalu saja sebatas pada claim yang sebenarnya debatable. 


\section{B. Beberapa Peristiwa Penting Ritual Istighosah}

Konteks tulisan ini didasarkan atas hasil penelitian terhadap ritual istighosah di Propinsi Jawa Timur. Fokus utama penelitian ini disandarkan pada beberapa momentum ritual istighosah yang menurut penulis dianggap cukup mewakili dalam memotret nilai-nilai perubahan makna. Diantara momentum ritual istighosah penting tersebut adalah; (1) Istighosah komunal pertama, di lapangan Tambaksari, 25 Desember 1997, (2) Istighosah II di parkir timur Senayan, 29 April 2001, (3) Istighosah III di lapangan Makodam V Brawijaya, 9 Maret 2003, (4) Istighosah Harlah NU ke-84 serentak di Jakarta, Lampung dan Lamongan, (5) Istighosah menjelang Pilgub Jawa Timur di Masjid al-Akbar, 18 Juli 2008, dan (6) Istighosah jama'ah ibuibu untuk kemenangan pasangan Pilgub Khofifah Indar Parawansa-Mujiono (KajiManteb), 15 Oktober 2008.

Alasan utama yang menguatkan pemilihan 6 (enam) momentum ritual istighosah meliputi beberapa pertimbangan mendasar, yakni; Pertama, dari keenam ritual istighosah dimaksud, penulis secara langsung terlibat aktif di dalamnya, baik sebagai panitia pelaksana maupun sebagai peserta. Sehingga, dari perspektif model penelitian etnografi, penulis tidak lain adalah sebagai participant observation.

Kedua, dari keenam momentum ritual tersebut, penulis melihat terdapatnya tahap-tahap perubahan yang signifikan untuk diteliti. Misalnya, jika pada penyelenggaraan ritual istighosah pertama (25 Desember 1997), baik motif tujuan maupun bentuk-bentuknya masih mendekati pada konsep istighosah dimaksud yang tetap "genuine", namun mulai dari penyelenggaraan ritual istighosah kedua, ketiga hingga case kelima mengalami perubahan-perubahan makna secara gradual. Ketiga, dari tahapan-tahapan ritual istighosah tersebut, baik secara jelas maupun agak kabur terdapat berbagai sistem simbol yang mudah ditangkap guna menjelaskan perubahan makna dibalik yang tersurat. Keempat, kecuali istighosah pertama, kelima ritual lainnya susah diukur hasilnya. Bahkan, pengukuran berdasarkan "bidden agenda" dibalik tujuan formal ritual itu, dapat dibilang gagal memenuhi target. Hidden agenda dimaksud adalah tujuan dibalik ritual ini sesungguhnya. Pada istighosah di lapangan parkir timur, senayan, hidden agendanya tidak dapat dilepaskan sebagai bentuk pressure atau show of force kekuatan politik di belakang Presiden Abdurrahman Wahid (Gus Dur) yang hendak digulingkan. Namun kenyataannya, Gus Dur beberapa hari berikutnya akhirnya diturunkan dari panggung kepresidenan. Hidden agenda ini juga nampak pada istighosah lainnya. 
Fenomena istighosah sangat menarik untuk diteliti. Sebab, sebagai bagian dari tradisi komunitas kelompok Islam tradisional $(\mathrm{NU})$, ia sebenarnya bagian dari salah satu simbol dari tradisi komunitas ini yang paling gunuine (asli) yang memiliki akar historis dari tardisi besar Islam dari sumber aslinya, Timur Tengah. .' Sayangnya, semenjak era transisi demokrasi Indonesia, mulai tahun 1997-1998, ritual ini mulai banyak di-public-kan. Kelihatannya, elite NU tidak ingin kalah "bersaing" dengan kelompok Islam lainnya, dimana masa transisi demokrasi lebih banyak ditandai dengan hadirnya Islam pada ruangruang publik politik. Disamping aspek positif tentunya, mobilisasi ritual istighosah di ruangruang publik secara terus menerus rupanya mau tidak mau membawa side effect negatif, yakni terjadinya perubahan makna dan nilai dalam konteks kebudayaan secara umum bagi komunitas Islam tradisionalis. Ritual yang awalnya hanya diselenggarakan pada momen-momen khusus saja dan pelaksanaannya di ruang-ruang tertutup, akhirnya digebyar di banyak momentum dan dilaksanakan secara publik di tempat lapang. Model mobilisasi ritual ini agaknya menyalahi prinsip-prinsip dan kodrat dari ritual itu sendiri.

Tahap selanjutnya, untuk menganalisis hadirnya berbagai sistem simbol yang tersurat bagi pemaknaan perubahan atas beberapa ritual istighosah tersebut, penulis menggunakan pendekatan interpretatif-simbolik yang dikembangkan oleh Geertz. Menurut Geertz, agama sebagai sebagai sistem kebudayaan memiliki peran pada 2 (dua) hal utama; (1) Agama sebagai model for atau pattern for perilaku keagamaan seseorang, disamping itu, (2) Agama juga berfungsi sebagai model of atau pattern of perilaku seseorang. Pada keduanya, agama mengandung fungsi sebaga sistem nilai, sistem kognitif dan sistem evaluatif dari konstruksi kebudayaan masyarakat tertentu. Menurut Geertz, untuk melihat ketiga sistem tersebut tentunya tidak dapat dilihat langsung. Cara untuk melihat dan memahami hakekat makna tersebut dapat dilakukan melalui sistem simbol yang hadir ditengah-tengah masyarakat maupun selama proses penyelenggaraan istighosah berlangsung. ${ }^{10}$

9 Menurut penulis, ritual istighosah, walau bisa saja disamakan atau dikatagorikan sebagai ritual slametan, namun keberadaannya berbeda dengan ritual yang kedua ini. Istighosah tidak banyak dipakai oleh komunitas dalam katagori abangan. Istighosah, disamping jarang atau tidak pernah dipraktekkan oleh kalangan abangan, ritual ini hanya dilaksanakan oleh komunitas santri (NU) pada momen-momen khusus saja. Ritual ini pun dilihat dari segi isi, cara maupun materinya tidak terdapat unsure-unsur sinkretisme Hindu seperti pada upacara slametan.

10 Agama dalam kaitannya dengan manusia memiliki dua fungsi; sebagai pola bagi tindakan (pattern for/mode for behavior) dan pola dari tindakan (pattern of/mode of behavior). Sebagai mode for, agama merupakan pedoman yang dijadikan kerangka interpretasi tindakan manusia. Sementara, arti agama sebagai mode of yaitu sesuatu yang hidup dalam diri manusia yang tampak dalam kehidupan sehari-hari. Hubungan antara mode for dan mode of terletak pada sistem symbol yang memungkinkan pemaknaan dilakukan. Lihat Nur Syam, Islam Pesisir, (Yogyakarta: LKiS, 2005), hal. 1. 


\section{Estetisasi Beragama}

Sebagaimana halnya ritual slametan, istighosah berisi konsep keseimbangan yang menghubungkan manusia dengan pencipta (Allah), mikro maupun makro kosmos. Geertz menggambarkan slametan sebagai upacara inti dari keseluruhan berbagai upacara dalam tradisi orang Jawa. ${ }^{11}$ Beatty mengistilahkan slametan sebagai jantungnya agama Jawa. ${ }^{12}$ Karenanya, slametan memiliki makna penting sebagai world view (pandangan dunia) mereka. Ia melambangkan kesatuan mistis dan sosial mereka yang ikut serta di dalamnya.

Upacaya istighosah semakin menemukan relevansi dan momentumnya, saat Indonesia berada pada transisi demokrasi. Pada catatan yang dapat diamati secara seksama, ritual istighosah semakin menjadi go public, bahkan menjadi trend. Disinyalir ada dua faktor yang melatarbelakangi; Pertama, saat-saat politik Indonesia memasuki era terakhir kepemimpinan Suharto dan memasuki masa-masa transisi politik Indonesia awal tahun 1998 hingga sekarang. Pada masa-masa ini, masyarakat Indonesia dihadapkan berbagai gejolak politik nasional, ancaman disintegrasi bangsa, peristiwa-peristiwa komunal yang saling ambigu, serta berbagai ancaman bencana, baik bencana sosial maupun bencana alam yang datang secara bertubi-tubi. Kedua, faktor tuntutan modernisasi atau modernisme yang dicirikan dengan kuatnya ideologi kapitalisme dan pasar global. Pengaruh fashion, pragmatisme, dan kekuasaan yang banyak menggunakan instrumen agama adalah faktor tak langsung yang ikut "memasarkan" dan membentuk image (persepsi) istighosah. Di sinilah, agaknya ritual ini mengalami komodifikasi.

Wacana diatas lambat laun membentuk ritual istighosah mengalami perubahan-perubahan makna. Tentunya, perubahan makna ini dapat ditangkap dan dijelaskan melalui sistem simbol yang hadir selama proses penyelenggaraan istighosah tersebut. Salah satu fenomena yang agak mudah ditangkap adalah terjadinya pergeseran makna, dari ritual yang sakral, inti, dan jantung bagi tradisi keagamaan Jawa, berubah menjadi “estetisasi" agama (istighosah). ${ }^{13}$ Beberapa

11 Geertz, Abangan, Santri,Priyayi..., Ibid, hal. 13-18.

12 Andrew Beaty, Variasi Agama di Jawa....., Ibid, hal. 39.

13 Dengan apik Irwan Abdullah melukiskan, bahwa masyarakat global saat ini mengalami apa yang disbutnya sebagai "deteritorialisasi" budaya. Faktor penyebabnya adalah "pasar". Kapitalisme (pasar) banyak merubah cara pandang, gaya hidup (life style) dan system nilai budaya masyarakat. Lihat Irwan Abdullah, Konstruksi dan Reproduksi Budaya, (Yogyakarta: Pustaka Pelajar, 2006), hal. 16-17. 
indikator yang nampak diantaranya ditandai; (1) dari ritual yang sakral berubah dalam bentuk simbol (sign), artifisial, ceremonial, ${ }^{14}$ yang kering dari subtansi makna. (2) dari hal yang bersifat tradisi, tuntutan world view, dan dogmatis menjadi hanya sekedar gaya hidup (live style).

Pada awal istighosah menjadi wacana publik (di luar komunitas NU), yakni pelaksanaan istighosah pertama, di Lapangan Tambaksari, 25 Desember 2007, agaknya tidak dijumpai perubahan makna maupun orientasi dari konsepsi ritual ini. Pembacaan peneliti ini dikuatkan dengan pemberitaan berbagai media massa. NU On-line misalnya, memberitakan pelaksanaan istighosah tersebut sebagaimana ilustrasi dan citra positif seperti di bawah ini:

"Persis tanggal 25 Desember 1997, doa bersama (istighosah) untuk pertama kalinya dilaksanakan secara terbuka di lapangan Tambak Sari, Surabaya, dipimpin oleh Ketua Pengurus Wilayah Nahdlatul Ulama (PWNU) Jawa Timur waktu itu KH. Hasyim Muzadi. Ternyata Istighotsah tersebut bisa terlaksana dengun khusyu' dan syahdu, sehingga bisa membawa ketenangan jiwa." 15

Namun, seiring dengan perubahan dimensi ruang dan waktu, beberapa ritual istighosah agaknya mulai dipengaruhi oleh kepentingan di luar dirinya. Indikator dari disorientasi makna dan tujuan seperti hasil temuan di bawah ini: Pertama, Dari ritual yang sakral berubah dalam bentuk sign, artifisial, dan seremonial. Fenomena ini nampak sekali misalnya dengan beberapa gejala, mulai dari mobilisasi massa dalam jumlah besar, biaya (cost) yang begitu besar, atribut (famlet, spanduk, baliho, ekspos media, jumlah kendaraan roda empat), kehadiran para tamu undangan (politisi, parpol, pebisnis, pejabat pemerintah, militer, dan pihak-pihak yang berkepentingan lainnya), dan masih banyak simbol lainnya.

14 Seremonial di sini tidak diartikan sebagai bentuk lain dari istilah inggrish dari ritual and ceremonial. Sebab, arti ceremonial dalam kamus antropologi dapat diartikan sebagai " $A$ fixed or sanctioned psttern of behavior which surrounds various phases of life, often serving relegius or aesthetic end and confirming the group's celebration of particular situation". Di mana, arti ceremonial di sini dipahami sebagai bentuk upacara keagamaan yang motif dan elemennya lebih besar dan rumit disbanding upacara dalam makna ritual. Lihat Irwan Abdullah, Simbol, Makna dan Pandangan Hidup Jawa: Analisis Gunungan pada Upacara Garebeg, (Yogyakarta: Balai Kajian Sejarah dan Nilai Tradisional, 2002), hal. 10. Ceremony dalam konteks istilah ini diambil dari pemaknaan public luas yang jauh dari ceremony dalam kajian Abdullah di atas. Ceremony dipahami sebagai upacara rutin, kenegaraan, public, yang hanya semata-mata karena tugas, dan - biasanya-jauh dari pemahaman akan makna yang terkandung di dalamnya.

15 NU On-line..., Ibid. 
Kesan ini agaknya kontras dengan pesan nilai yang hendak disampaikan dalam ritual tersebut. Pesan-pesan moral agaknya susah ditangkap ditengah hiruk pikuk massa yang berdesak-desakan, penuh dengan peluh dan keringat akibat panasnya sengatan matahari. Sayup-sayup yang terdengar adalah iringan lantunan doa-doa istighosah. Tausiyah maupun fatwa tidak dapat ditangkap dengan jelas, kecuali oleh mereka yang punya kepentingan untuk melakukan ekspos bagi kepentingan pemberitaan di media massa.

Konsekwensi dari disorientasi ini, ritual yang semestinya penuh dengan tadarruan wa hufyah (ratapan dan ketakutan), berubah menjadi sign (tanda), bersifat artifisial, bahkan seremonial. Pesan makna yang semestinya lebih subtansial menjadi agak kabur, atau bahkan tidak ditangkap sama sekali oleh massa yang hadir. Boleh jadi, hal ini disebabkan karena pengaruh dari luar yang disebut di atas juga karena unsur komodifikasi para elit yang terlibat dalam perhelatan istighosah itu. Untuk alasan yang terakhir ini dapat dilacak dari keberatan beberapa Kyai yang tidak pernah terekspos di media massa. Pertama, pada awalnya, terjadi perdebatan diantara para Kyai seputar baik buruknya penyelenggaraan istighosah yang dilakukan di ruang terbuka dengan mengerahkan ratusan ribu orang dari berbagai penjuru daerah. Alasan utama adalah ketidak kyusu'an. ${ }^{16}$ Kedua, pada istighosah yang dilaksanakan secara live, di Istora Senayan, Jakarta, Lampung dan Lamongan, Jawa Timur, tepat pada harlah NU ke-84 sempat beredar perdebatan di kalangan Kyai. Pokok perdebatannya adalah penyederhanaan materi istighosah sebagaimana yang telah "di-pakem-kan" oleh Ulama Jawa Timur. Alasan yang beredar di kalangan penyelenggara di Jakarta, karena istighosab kali itu dihadiri oleh Presiden, duta besar negara-negara sahabat, kalangan militer dan berbagai tamu undangan penting lainnya. Jika prosesi pelaksanaan istighosah memakan waktu cukup lama dirasa akan melelahkan para tamu istimewa. Alasan tersebut dirasa mengada-ngada dan mereduksi makna istighosah itu sendiri. Tidak mengherankan, apabila kecenderungan semakin menguatnya gejala perubahan makna istighosah menjelma menjadi sekedar sign (tanda), sesuatu yang artifisial dan ceremonial semakin kuat.

Kedua, dari Prinsip World View menjadi sekedar gaya hidup (live style). Argumentasi hasil temuan yang menguatkan pandangan ini memang dapat diperdebatkan. Namun beberapa argumentasi atas hasil observasi sepertinya menunjukkan gejala-gejala ke arah itu. Dalam fungsinya, agama sebagai pola dari 
tindakan pengikutnya, agaknya ritual istighosah telah lama dan terlalu sering "dipentaskan" di depan publik. Fungsi istighosah dari sumber utama (kalangan ahli Tarekat) yang hanya digelar dalam kondisi-kondisi tertentu yang sangat genting, sepertinya telah dinegasikan. Siapa saja tidak akan pernah mencapai titik temu apa yang dimaksud dengan kondisi genting. Apa ukuran atau indikator suatu keadaan dianggap genting. Dan masih banyak lagi hal lain yang dapat diperdebatkan. Tetapi, suatu hal yang jelas, motif dibalik perhelatan istighosah dalam lokus penelitian ini, empat diantaranya karena alasan doa untuk keselamatan bangsa dan satunya adalah doa untuk minta aman dan suksesnya pelaksanan Pilkada di Jawa timur. Namun demikian, sekali lagi mengukur indkator motif dibalik istighosah adalah sesuatu yang absurd. Pertanyataannya misalkan, betulkah Indonesia dalam keadaan gawat? Seberapa gentingkah kondisi bangsa ini? Adakah ukuran pasti 5 atau 10 tahun lagi Indonesia akan hancur? Serta pertanyaan lain yang relevan.

Menurut pengamatan di lapangan, setelah usai pelaksanaan istighosah I, di Tambaksari, ritual istighosah menjadi sering dilaksanakan, tidak hanya oleh kalangan NU, melainkan juga berbagai kalangan muslim lainnya. Motif penyelenggaraan istighosah juga mulai beragam, tidak hanya melulu berdoa untuk masalah-masalah besar saja. Persoalanpersoalan yang dialami oleh berbagai segmen masyarakat, dalam kebuntuan penyelesaiannya sering kali menggunakan media ritual istighosah sebagai sarana untuk menyelesaikan kasus-kasus tersebut. Istighosah dilihat dari cover areanya tidak lagi mencakup skala nasional, bahkan regional, kabupaten, kecamatan, dan tidak jarang dilakukan oleh komunitas dalam sekup lokal. Singkatnya, istighosah pada dekade beberapa tahun terakhir diselenggarakan mulai dari kantor pemerintahan, instansi, pabrik, sekolahan hingga buruh pabrik maupun komunitas kecil tertentu yang sedang merasa tertindas.$^{17}$

Fenomena munculnya beragam komunitas yang sedikit-sedikit menghelat istighosah sebagai medium dalam menyelesaikan persoalan tak ubahnya seperti fenomena McDonalisasi pada kajian posmodernisme Baudrillard. ${ }^{18}$ Argumen ini tidak hendak berpretensi negatif tentang perubahan makna dalam istighosah. Memang tidak sepenuhnya negatif, McDonalisasi ritual istighosah dalam praktek kehidupan masyarakat beragama di Indonesia. Walaupun tidak bisa dihindari ekses negatif selalu saja hadir ditengah-tengah "publisisasi" ritual istighosah ini. Dalam

17 Berkas http://mtsn-prob.com/index2.php?option=com_content\&do_pdf=1\&id=59, 24 April 2008.

18 George Ritzer \& Goodman, Douglas J, Teori Sosiologi: Dari Sosiologi Klasik Sampai Perkembangan Mutakhir Teori Soisal Postmodern, (Yogyakarta: Kreasi Wacana, 2008), hal. 618-19. 
beberapa kasus ditemukan, tidak sedikit istighotsah yang dilaksanakan untuk tujuan politik praktis. Bahkan banyak pula dijumpai usaha "mengkomersialkan" istighotsah, sehingga penyelenggara dan Ustaz yang memimpinnnya menjadi kaya raya dan terus menyelenggarakan istighotsah di berbagai tempat. ${ }^{19}$ Model penyelenggaraan ritual yang bernuansa komersial mendapat kritik tajam dari ketua umum PBNU. Menurut KH. Hasyim Muzadi, model istighosah demikian, merupakan bentuk penyimpangan yang tidak sehat dari istighotsah terbuka yang dilaksanakan, padahal tujuan awal istighotsah adalah untuk keselamatan bangsa Indonesia secara keseluruhan. Karena itu saat ini NU juga menganjurkan pada wilayah dan cabangcabang untuk terus melaksanakan istighotsah yang sesuai dengan tujuan semula. ${ }^{20}$

Fenomena McDonalisasi dalam konteks istighosah tanda-tandanya adalah kuatnya dugaan akan penyelenggaraan istighosah yang berubah fungsi menjadi gaya hidup (live style). Makanan siap saji (McDonald), sebuah bisnis di bawah satu kepemilikan, Euro Disney, mampu menarik dan mempengaruhi masyarakat di seluruh dunia. Fantasi orang saat mendengar McDonald, tidak lain adalah keinganan untuk mencoba menikmati. ${ }^{21}$ Karena prinsip coba-coba, lambat laun menjadi trend dan sekaligus gaya hidup.

Konteks yang sama kelihatannya ditemukan dalam berbagai ritual istighosah akhir-akhir ini. Baik dalam lokus penelitian maupun istighosah yang dilakukan oleh berbagai komunitas lainnya, — baik dari aspek motif tujuan maupun sistem penanda (sistem simbol) yang melingkupinya — menunjukkan adanya gejala menuju hanya sekedar gaya hidup saja. Pada aspek yang pertama dapat dilihat dari maraknya (trend) setiap masalah selalu merasa dapat diselesaikan melalui pendekatan ritual istighosah. Dari istighosah komunal pertama di Tambaksari hingga istighosah 18 Juli 2008 menjelang pelaksanaan Pilkada Jawa Timur, rasionalitas yang dibangun adalah sama, yakni menyandarkan pada Tuhan terhadap persoalan yang dirasa tidak dapat diselesaikan oleh rasio manusia. Sementara, aspek yang kedua dapat juga ditunjukkan gejala-gejalanya di sini sebagai berikut; pertama, simbol konsumerisme. Biaya penyelenggaraan ritual istighosah secara nominal relatif membutuhkan biaya yang tidak sedikit. Begitu juga dengan bekal yang harus ditanggung pada setiap individu jama'ah untuk dapat hadir pada ritual ini. Unsur plesiran atau rekreasi (ke kota) dalam banyak kasus juga menjadi motivasi dibalik kedatangan seseorang menghadiri ritual ini. Hal lain yang sering menjadi bagian

19 NU Online, 19 Januari 2007 ..., Ibid.

20 Ibid.

21 George Ritzer \& Goodman Douglas J, Teori Sosiologi ..., hal. 619. 
tidak langsung adalah transaksi ekonomi yang demikian tinggi, antara pedagang dan massa yang hadir. Kedua, simbol kontestasi fashion show. Bertolak belakang dari prinsip istighosah yang mengedepankan tadarruan wa kufyah, peserta biasanya menampilkan atribut yang bersifat fashion. Misalnya atribut pakaian yang mahal atau baru, kendaraan (transportasi) dengan mobil-mobil yang berkelas. Ketiga, simbol kontestasi pengaruh. Nuansa lain dari perayaan ritual ini adalah kontestasi pengaruh "kekuasaan", baik tokoh nasional, regional maupun tokoh lokal. Kehadiran pejabat, politisi, pebisnis atau elite undangan lainnya kiranya tidak dapat dilepaskan dari kontestasi dan perebutan pengaruh. Realitas ini semua cukup menjadi bukti kuat sebagai pergeseran dari makna prinsip world view ke arah life style.

\section{Politisasi Istighosah}

Pasca tumbangnya rezim Suharto, fenomena yang menarik dilihat adalah kembalinya agama pada ruang-ruang publik dan panggung politik terbuka. Fenomena ini ditandai dengan hadirnya beberapa Parpol yang nyata-nyata berbasis pada ideologi agama maupun menggunakan simbol-simbol agama secara menyolok. Keadaan ini memang bisa dianggap euforia. Sebabnya adalah, selama era Suharto, agama selalu dicurigai sebagai ancaman terhadap stabilitas kehidupan berbangsa, konsekwensi dari ini semua adalah agama harus dikebiri menjadi semata urusan personal. Nampaknya, ritual istighosah pada dekade-dekade tersebut dapat dibaca dalam konteks euforia tersebut. Sehingga, tidak berlebihan jika wacana publik yang berkembang luas selalu menjustifikasi istighosah tidak dapat dipisahkan sepenuhnya dari interest-interest kepentingan politik praktis, langsung maupun tidak langsung.

Sinyalemen di atas kiranya susah ditepis. Kecuali penyelenggaraan istighosah I di lapangan Tambaksari, Surabaya, istighosah selanjutnya nampaknya tidak dapat disterilkan dari dugaan-dugaan kepentingan politis praktis. Dari pengamtan di lapangan terhadap sistem simbol yang hadir sepertinya memang sulit dipungkiri adanya asumsi di atas. Gejala hadirnya kepentingan politik praktis ditandai dengan beberapa ciri; Pertama, penyelenggaraan istighosab selalu bersamaan dengan momentum politik nasional maupun lokal. Selain istighosah pertama, paling tidak dilihat dimensi waktu-waktu penyelenggarannya patut diduga adanya muatan lain, selain motif instrinsik dari ritual itu sendiri. Dilihat dari setting waktu, pelaksanaan istighosah kedua, ketiga dan seterusnya berbarengan atau menyongsong momentummomentum politik, baik politik pada lanskap nasional maupun lokal. 
Istighosah di lapangan Parkir Timur senayan pada 29 April 2001, dilihat dari lanskap peta politik nasional saat itu berhimpitan dengan rencana sidang istmewa MPR yang berencana menggulingkan Abdurrahman Wahid dari tampuk kekuasaannya di kursi kepresidenan. Mobilisasi massa yang hadir, disamping telah disiapkan untuk istighosah, hari berikutnya dengan massa yang sama dimobilisasi untuk kepentingan demontrasi besar-besaran menentang sidang MPR yang ingin menjatuhkan presiden Gus Dur. Masa istighosah dimobilisasi sebagai bentuk pressure dan show of force kekuatan politik untuk tetap mendukung sepenuhnya terhadap Gus Dur di panggung politik kepresidenan. Walaupun PBNU -sebagai institusi penyelenggara-sendiri dengan tegas menolak anggarapan adanya motif ganda tersebut. Dalam siaran persnya, PBNU, melalui Masduki Baidlowi mengatakan, "Kegiatan PBNU hanya istighotsah. Di luar itu, bukan tanggungjawab kami, tapi tugas kepolisian." 22 Hari berikutnya memang benar terjadi, sebagian besar massa yang hadir pada ritual istighosah tersebut, termasuk banyak Kyai, terlihat ikut turun ke jalan menuju gedung DPR dalam rangka mendukung presiden Gus Dur dan menolak sidang Istimewa MPR.

Penyelenggaraan Istighosah di lapangan Makodam V Brawijaya, pada tanggal 9 Maret 2003 tidak dapat dipisahkan dari lanskap peta politik propinsi Jawa Timur. Pada 2004, Jawa Timur mempunyai jahatan politik lima tahunan yang dikenal dengan Pemilihan Gubernur 2004. Nuansa Istighosah ini tidak sepenuhnya dapat dipisahkan dari tarik-tarik menarik dukungan kepada kandidat tertentu, walaupun saat itu, pemilihan Pilkada belum melibatkan suatu rakyat secara langsung, tetapi masih menggunakan prinsip keterwakilan melalui DPRD. Meskipun warga tidak mrmilih secara langsung, atmosfir politik saat itu masih kental dengan dukungan simbolik melalui pernyataan sikap atau sign (tanda) dukungan dalam bentuk lain. Kondisi yang kurang lebih sama juga terlihat lagi pada ritual istighosah, baik di Masjid Akbar, 18 juli 2008 atau istighosah yang dilaksanakan oleh ibu-ibu karena diundang oleh Tim Sukses pasangan calon gubernur dan wakil gubernur pasangan Khofifah Indar Parawansa dan Mujiono, 15 Oktober 2008. Pada ritual istighosah di Masjid Akbar, dengan motif meminta keamanan dan kesuksesan penyelenggaraan Pilgub Jawa Timur, yang hadir pada kesempatan tersebut antara lain adalah calon gubernur Khofifah Indar Parawansa, Sukarwo, dan calon wakil gubernur Ali Maschan Moesa, serta Ridlwan Hisyam.

22 Tempo Interaktif, Di Luar Istighosah Bukan Urusan PBNU, Senin, 23 April, 2001. 
Kedua, sebagai show of force kekuatan politik. Indikator terhadap pembacaan ini dapat disimak dari besarnya mobilisasi massa yang dihadirkan. Kehadiran jumlah massa yang begitu besar jelas-jelas menjadi sistem simbol tersendiri bagi para elite NU, secara tidak terang-terangan ditunjukkan kepada kelompok-kelompok kepentingan lain di luar komunitas NU itu sendiri. Sebab, dalam era seperti sekarang ini, rasanya amat sulit bagi kekuatan ormas, orsospol maupun kelompok tertentu dalam waktu tertentu dapat menghadirkan massa dalam jumlah sebesar itu. Pemerintah sekalipun, rasanya agak sulit dapat menghadirkan jumlah massa dengan kuantitas sebesar itu, tanpa meminta imbalan apapun. Di sinilah, elite NU mampu membuktikan dan melakukannya. Secara implisit, mungkin saja elite-elite NU tertentu hendak ingin menunjukkan, bahwa NU memiliki "power" besar dan semestinya patut diperhitungkan dalam percaturan politik nasional. Dengan bahasa yang lebih soft atau dalam perspektif yang lebih positif, ada pengamat yang mengatakan, bahwa istighotsah juga berarti partisipasi publik dalam rangka ikut berperan aktif dalam membantu memecahkan problematika bangsa. Apabila partisipasi publik diartikan sebagai "taking part in the processes of formulation, passage, and implementation of public policy" with "actions aimed at influencing decisions made by public representatives." 23

Dalam politik simbolik, kekuatan seseorang atau institusi yang dapat menghadirkan ribuan massa secara "sukarela" dapat dibaca sebagai orang atau institusi yang demikian powerfull. Pengaruhnya demikian luas, melebihi batas-batas dimensi ruang dan waktu. Relasi dari berbagai tingkatan status ekonomi dan kelas social, —dari grass-root hingga kaum menengah dan elite- menempatkannya untuk melakukan komunikasi politik secara fleksibel dan luwes. Konsekwensinya, ia memiliki pengaruh luas yang dengan mudah diterima oleh kalangan tersebut. Tanpa disadari, massa yang demikian besar, ditopang oleh isntitusi sosial (NU) yang estabelish (mapan), merupakan modal politik besar bagi elite tersebut. Atas dasar pemikiran ini, rasanya memang tidak berlebihan jika momentum pada ritual-ritual istihgosah dalam beberapa kasus terakhir dapat dimaknai sebagai symbol dari "show of force" kekuatan politik. Fenomena ini paling tidak dapat ditangkap dengan jelas pada ritual istighosah di lapangan Parkir Timur Senayan. Pada ritual ini, nampaknya susah dipungkiri sebagai unjuk kekuatan (show of force) para pendukung presiden Gur Dur terhadap lawan atau musuh-musuh politiknya.

23 Nur Sholikhin, “NU dan Tradisi Istighosah: Politis atau Ritual?”, Kompas, Sabtu, 8 Maret 2003. 
Ketiga, hadirnya orang "penting" dan orang "kuat" pada ritual tersebut. Di berbagai ritual istighosah, dijumpai banyaknya tamu undangan VIP yang menempati deret barisan pertama atau kedua di panggung utama. Tamu "istimewa" datang dari berbagai status kelas sosial menengah-atas di negeri ini. Bahkan, tidak jarang juga dijumpai berbagai tamu utusan luar negara lain. Unsur-unsur ini antara lain; presiden, wakil presiden, menteri negara, petinggi militer, politisi kelas wabid, gubernur, bupati atau walikota, dan para pengusaha. Disamping mereka juga ditemukan utusan khusus dari duta besar negara sahabat, diplomat, dan para pemerhati luar negeri. Bahkan, pada suatu istighosah, presiden Lybia, Muammar Qadhafi juga secara khusus pernah datang ke ritual istighosah yang dihelat di Masjid Akbar Surabaya, di tengah-tengah kesibukannya menghadiri Konferensi Tingkat Tinggi (KT'T) negara Asia-Afrika di Bandung. Kehadiran Qadhafi ini dikatannya sebagai kunjungan balasan Hasyim Muzadi saat berkunjung di negaranya, Lybia. ${ }^{24}$ Kehadiran mereka dapat dilihat jelas oleh massa yang ber-jubel dan berdesak-desakan di bawah panggung itu.

Pemandangan atas kehadiran para tamu "khusus" ini menggiring opini publik pada kesimpulan yang berbeda-beda. Satu sisi dapat dimaknai, bahwa elite NU masih memiliki power dan bergainning position besar dihadapan para elite penguasa. Di sisi lain, bagi mereka yang berpikiran positif mengatakan, bahwa kehadiran mereka menggambarkan pada realitas akan pentingnya posisi NU sebagai ormas keagamaan yang memerankan diri sebagai perekat diantara kelompok anak bangsa yang heterogen dan multikultur. ${ }^{25}$ Lebih dari itu, ulasan para pemerhati maupun pihakpihak di luar komunitas NU tidak jarang menyimpulkan dengan mengatakan, bahwa ritual istighosah telah berubah menjadi ajang kontestasi kekuatan politik tertentu dengan menggunakan media istighosah itu. Dengan kata lain, dari perspektif politik, kiranya memang terdapat kesan kuat adanya perubahan makna formal istighosah ini, dari sesuatu yang bersifat sakral maupun tradisi telah mengarah kepada politisasi istighosah itu sendiri.

24 “Ribuan Polisi Amankan Muammar Qaddafi”, Surabaya Post, Selasa, 16 April 2005.

25 Doktrin NU melalui Aswaja-nya memang memegang dan menekankan prinsip-prinsip -i’tidâl (keadilan), tasammub (toleran), tawâzzun (keseimbangan), tawassut (moderat/di tengah-tengah), dan amal ma'ruf nahi al-munkar. Prinsip dasar ini yang menjadi pedoman hidup warga NU menjadi modal sosial dalam konteks tindakan dan perilaku warga NU dalam berhubungan dengan sosial, kemasyarakatan dan kenegaraan. Lihat KH. Achmad Siddiq, Khittah an-Nabdliyah 1926, (Surabaya: Khalista, 2007), hal. 12-13. 


\section{E. Perubahan Relasi Kyai-santri}

Walau bukan sebagai faktor satu-satunya, mobilisasi massa dalam berbagai ritual istighosah ternyata justeru berdampak negatif bagi keberlangsungan relasi Kyaisantri. Akibat dari penggambaran dimensi negatif seperti pada analisis-analisis sebelumnya, forum berbagai ritual istighosah lambat laun menciptakan "ruang" image dan konstruksi pemikiran warga nabdliyin akan semakin jauhnya keterlibatan para elite kyai pada ranah politik praktis dan penuh kepentingan sesaat. Realitas ini diperparah dengan momentum-momentum politik praktis, baik pemilihan presiden (Pilpres), pemilu gubernur (Pilgub), maupun pemilihan bupati (Pilbub). Pada beberapa peristiwa politik rutin ini, para elite kyai memang selalu menjadi "medan magnet" dan menjadi daya tarik luar biasa bagi politisi untuk menjadi "mesin politik" bagi kemenangan pasangan politik tertentu. Kyai sebagai simbol panutan warga (santr) agaknya -dalam banyak kasus — sulit menghindar dari tawaran-tawaran politik sesaat (praktis) karena iming-iming materi menjanjikan. Akibatnya, relasi patron-client, yang menempatkan kyai sebagai patron mulai dipertanyakan tingkat relevansinya. Dalam berbagai diskusi yang berkembang di tengah-tengah warga NU, politik tidak lain adalah wilayah yang kotor, penuh tipu muslihat, instrik, dan kebohongan. Kyai, dalam pandangan mereka, disamping memang tidak cocok pada wilayah tersebut, juga dianggap tidak memiliki seperangkat "ilmu" untuk terjun pada kancah tersebut. Akibatnya, kehadiran mereka tidak merubah kultur politik yang lebih baik, tetapi malah sebaliknya, para kyai ikut larut dalam irama politik yang jauh dari nilai-nilai etis demokratis yang seharusnya dijunjung tinggi.

Secara teoritis, dalam kajian patron-client, terdapat prasyarat-prasyarat pengandaian akan tetapnya survavilitas relasi patron-client. Setidaknya, menurut James C. Scott, terdapat 3 (tiga) unsur utama yang menopang keberlangsungan relasi patron-client atas hasil temuannya saat meneliti di Asia Tenggara; (1) Terdapatnya perbedaan (inequality) yang mencolok dalam kepemilikan atas kekayaan, status serta kekuasaan, (2) Adanya pranata-pranata yang menjamin keamanan individu, baik yang menyangkut status ataupun kekayaannya, (3) Ketergantungan kelas sosial tertentu terhadap kelas sosial lainnya, karena faktor kekerabatan, ekonomi, atau jasa. ${ }^{26}$ Relasi patron-client ini umumnya memang bersifat cair. Tidak ada ikatan khusus secara tertulis. Bahkan, seperti ditunjukkan oleh Scott dan Foster, seorang

26 Heddy Shri Ahimsa Putra, Patron dan Klien di Sulawesi Selatan: Sebuah Kajian FungsionalStruktural, (Yogyakarta: Kepel, 2007), hal. 30-31. 
client pun bisa memutuskan ikatan dengan patron-nya jika dia merasa tidak adanya keseimbangan lagi dalam hubungan timbal-balik mereka, artinya, si client merasa dirugikan, atau merasa dieksploitasi menurut istilah Wertheim. ${ }^{27}$

Di samping bertumpu pada pada teori patron-client, terdapat pendekatan lain yang dirasa lebih soft dalam melihat perubahan relasi kyai-santri, yakni konsep kharisma dan rutinisasi dari Weber. ${ }^{28}$ Menurut Weber, kharisma akan tetap terjaga manakala ada usaha-usaha secara kontinyu untuk mempertahankannya. Usaha kontinyu ini disebutnya sebagai "rutinitas". Dalam contoh tersebut, Schroeder memang tidak menyebut secara jelas bagaimana metodenya. Namun dia menjelaskan, salah satu cara mempertahankan kharisma adalah proses regenerasi kepada anak atau keturunan lainnya agar sistem kekerabatan (meminjam istilah Scott) tetap terjaga. Dan satu lagi, menurut Weber, seperti tafsir Schroeder, kharisma akan luntur karena proses modernisasi. Hal ini seperti ilustrasi hadirnya kapitalisme yang mau tidak mau meruntuhkan sistem kharisma dalam tradisi kristen calvinis.

Dalam konteks pemaknaan terhadap ritual istighosah, khususnya istighosah yang diselenggarakan oleh NU terdapat relevansinya. Hal ini mengingat, pelaksanaan istighosah ini melibatkan dan memolisasi massa grass-root secara total. Mobilisasi massa dilakukan oleh institusi NU pada level pengurus Cabang. Pengurus Cabang juga memobilisir massa di tingkat institusi di bawahnya, yakni Pengurus Wakil Cabang (MWC) hingga ke pengurus Ranting (level desa). Disamping mereka yang datang secara pribadi-pribadi, terdapat massa yang memang dimobilisir oleh para Kyai berbasis pada pondok pesantren masing-masing, jaringan santri, jama'ah atau masyarakat sekitar. Tetapi, satu hal yang pasti, bahwa massa yang hadir adalah komunitas santri yang secara geneologis memiliki ikatan relasi kyai-santri, baik secara langsung maupun tidak langsung. Dan gambaran ini adalah realistis. Santri di komunitas tertentu, jika ditelusuri ia akan ketemu pada partalian dengan relasi kyai tertentu. Relasi kyai-santri ini melewati batas-batas dimensi ruang dan waktu.

Problematika mulai muncul di saat relasi keduanya mulai dipertanyakan oleh salah satu diantaranya. Bisa saja Kyai mulai meragukan komitmen santri di suatu tempat karena dianggap tidak lagi "patuh" pada "fatwa" politik kyai. Kasus ini banyak ditemukan, khususnya pada momentum-momentum Pilkada. Sebaliknya,

27 Ibid, hal. 30.

28 Dalam kajiannya pada sub-bab kharisma dan rutinisasi, Ralph Schroeder menganalisis, bahwa kharisma akan langgeng manakala terdapat aspek rutinisasi. Lihat Ralph Schroeder, Max Weber: Tentang Hegemoni dan Sistem Kepercayaan, (Yogyakarta: Kanisius, 2002), hal. 22-28. 
dalam banyak kasus juga ditemukan mulai ragunya komunitas santri terhadap kepatron--an Kyai. Isu-isu "politisasi" istighosah yang banyak beredar, baik melalui berita di media massa ataupun lewat kasak-kusuk dari mulut satu ke mulut yang lain ikut berperan besar atas renggangnya relasi keduanya.

Akibatnya, pada batas-batas tertentu, juga di daerah-daerah tertentu, relasi Kyaisantri mulai dipertanyatakan, terutama oleh para client, santri. Dalam konteks politik khususnya, client merasa tidak lagi bergantung pada patron mereka. Meminjam istilah Scoot, kondisi ini disebabkan karena tidak adanya keseimbangan antara apa yang didapat oleh patron dan client. Nilai keseimbangan dimaksud dapat saja diukur dari aspek materi (pragmatis) maupun pada aspek lainnya; mulai dari relasi, pengaruh, bahkan pada aspek kekuasaan walau tidak didapat secara langsung oleh si patron.

Fenomena ini agaknya dapat dibaca dari penyelenggaraan istighosah satu ke ritual yang sama di kesempatan lain. Pada kasus istighosah di Masjis al-Akbar, yakni pada momentum menjelang Pemilihan Gubernur (Pilgub) dan istighosah yang digagas oleh tim sukses pasangan gubernur dan wakil gubernur Khofifah Indar ParawansaMujiono (Kaji-Manteb), massa yang hadir tidak sebanyak dari ritual serupa sebelumnya. Bahkan, jumlah massa jauh dari target. Lebih dari itu, massa yang didatangkan tidak lagi didasarkan atas instruksi kepada pengurus struktural di bawahnya, melainkan melalui kumpulan jama'ah tarikat atau jama'ah Bahkan, jumlah massa jauh dari target. Lebih dari itu, massa yang didatangkan tidak lagi didasarkan atas instruksi kepada pengurus struktural di bawahnya, melainkan melalui kumpulan jama'ah tarikat atau jama'ah yasinan di beberapa titik dan massa yang didatangkan tidak lagi bersifat sukarela. Kehadirannya dimobilisir dengan disediakan sarana transportasi atau dana pengganti trasnportasi. Bahkan, untuk kasus istighosah yang dihelat oleh Tim Kaji manteb, ibu-ibu jama'ah yang hadir mendapat bingkisan, berupa baju dan kerudung.

Beberapa fenomena ini kiranya cukup memberi ilustrasi akan mulai memudarkan relasi patron-client tersebut. Sikap yang ditunjukkan pada beberapa momentum istighosah tidak lagi didasarkan atas tidak ketergantungan si-client terhadap si-patron. Unsur-unsur sukarela, prinsip keseimbangan, dan saling membutuhkan agaknya tidak ditemukan. Yang muncul adalah rasionalisasi atas dasar untung rugi. Siapa yang membutuhkan dan siapa yang dibutuhkan. Fenomena ini memang secara khusus memotret relasi kyai-santri dalam konteks urusan politik. Kiranya, pudarnya relasi keduanya belum tentu ditemukan dalam konteks relasi pada aspek lainnya; misalnya aspek ajaran nilai keagamaan, sosial, pendidikan dan lain sebagainya. 


\section{F. Penutup}

Ternyata, setelah ritual istighosah dianalisis dengan menggunakan pendekatan interpretatif-simbolik membuka cakrawala baru serta cukup memberi gambaran jelas terhadap perubahan-perubahan makna dari ritual istighosah dan berujung pada perubahan sistem kognitif dan sistem nilai pada kebudayaan kelompok Islam tradisionalis. Perubahan tersebut secara garis besar adalah mulai terjadinya desakralisasi terhadap tradisi-tradisi keagamaan yang dipunyai oleh warga NU.

Sedangkan perubahan-perubahan derivatif dari makna desakralisasi terhadap tradisi keagamaan dimaksud dapat dirangkum dalam 3 (tiga) aspek mendasar; pertama, Beralihnya ritual istighosah dari yang bersifat sakral menjadi sesuatu yang hanya sekedar estetis, profan. Kedua, dari suatu tradisi ritual yang bersifat "instrinsik", murni keagamaan berubah menjadi nuansa yang bersifat politis. Ketiga, mulai memudarnya relasi patron-client kyai-santri. Walau bukan aspek penyebab satusatunya, momentum istighosah dapat diukur dalam menilai perubahan tata nilai tersebut. Sikap yang ditunjukkan pada beberapa momentum istighosah tidak lagi didasarkan atas tidak ketergantungan si-client terhadap si-patron.

\section{DAFTAR PUSTAKA}

Abdullah, Irwan. 2002. Simbol, Makna dan Pandangan Hidup Jawa: Analisis Gunungan pada Upacara Garebeg. Yogyakarta: Balai Kajian Sejarah dan Nilai Tradisional.

—. 2006. Konstruksi dan Reproduksi Budaya. Yogyakarta: Pustaka Pelajar.

Ahimsa, Heddy Shri. 2007. Patron dan Klien di Sulawesi Selatan: Sebuab Kajian Fungsional-Struktural. Yogyakarta: Kepel.

Beatty, Andrew. 2001. Variasi Agama di Jawa: Suatu Pendekatan Antropologi. Jakarta: PT. Rajagrafindo Persada.

Geertz, Clifford. 1983. Abangan, Santri, Priyayi dalam Masyarakat Jawa. Jakarta: Pustaka Jaya.

George Ritzer \& Goodman, Douglas J. 2008. Teori Sosiologi: Dari Sosiologi Klasik Sampai Perkembangan Mutakhir Teori Soisal Postmodern. Yogyakarta: Kreasi Wacana. 
Hefner, Robert W. 1985. Hindu Javanes: Tengger Tradition and Islam. Princeton: Princeton University Press.

http://mtsn-prob.com/index2.php?option=com_content\&do_pdf=1\&id=59, 24 April 2008.

Mulder, Niels. 1999. Agama, Hidup Sehari-hari dan Perubahan Budaya. Jakarta: Gramedia Pustaka Utama.

- 2007. Mistisisme Jawa: Ideologi di Indonesia. Yogyakarta: LkiS.

NU Online. 2006. “Ubudiyah”. Kamis, 23 Juni.

_.2007. "Mengawali Istighosah". 19 Januari.

Schroeder, Ralph. 2002. Max Weber: Tentang Hegemoni dan Sistem Kepercayaan. Yogyakarta: Kanisius.

Sholikhin, Nur. 2003. "NU dan Tradisi Istighosah: Politis atau Ritual?”, Kompas, Sabtu, 8 Maret.

Siddiq, Achmad. 2007. Khittah an-Nabdliyah 1926. Surabaya: Khalista.

Surabaya Post. 2005. "Ribuan Polisi Amankan Muammar Qaddafi”. 16 April.

Syam, Nur. 2005. Islam Pesisir. Yogyakarta: LKiS

- 2007. “Tradsisi Perempuan Meminang di Kabupaten Tuban”, dalam Mad₹̧̧abmadzhab Antropologi. Yogyakarta: LKiS.

Tempo Interaktif. 2001. "Di Luar Istighosah Bukan Urusan PBNU”. Senin, 23 April. Woodward, Mark. 2006. Islam Jawa: Kesalehan Normatif Versus Kebatinan. Yogyakarta: LKiS. 